TITLE:

\title{
A Mathematical Approach to Spatial Distribution and Temporal Succession in Plant Communities(Abstract_要旨 )
}

\section{AUTHOR(S):}

Yamamura, Norio

\section{CITATION:}

Yamamura, Norio. A Mathematical Approach to Spatial Distribution and Temporal Succession in Plant Communities. 京都大学, 1977, 理学博士

ISSUE DATE:

1977-01-24

URL:

http://hdl.handle.net/2433/221308

RIGHT: 
氏 名湈禁則男

学位の種類理 学 博士

学位記番号理 博 第 430 号

学位授与の日付 昭和 52 年 1 月 24 日

学位授与の要件学 位 規 則第 5 条第 1 項該 当

研究科・専攻理学研究科物理学第一専攻

学位論文題目 A Mathematical Approach to Spatial Distribution and Temporal Succession in Plant Communities

(植物群集の空間分布と遷移の数学的解析)

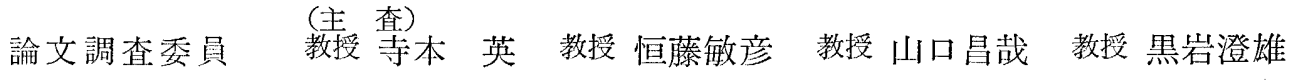

\section{論 文内容 の 要 旨}

環境条件が連続的に変化している地域に抢いて，植物の種の空間分布に不連続的な境界が形成さ扎る場 合があることは上く知られた事実である。高山の麓から頂上にわたっての植物分布，湖沼の水辺からの距 離によって変化する植物種の分布などは典形的な例である。こうした植物群集の空間分布のパターンの形 成は, 種の增殖率汶対する環境条件の適応性の違いと, 種間の競合関係の結果として出現することは容易 に想定されることであるが，不連続的な境界の形成のメカニズムについての数理生態学的な議論はまだま ったくなされていない。

申請者は, たがいに競合関係にある 2 種の個体数密度の変動を記述するボルテラ方程式を基礎にして, 遷移の過程を通してこの 2 種の空間分布に不連続的な境界が形成される可能性があることを証明してい る。さらに, 同じ数学的モデルから導かれる結果にもとづいて, 植物生態系の遷移の過程がゆっくりした 種の交代によって起る場合と, 微妙な環境变化の違いによって急激な種の交代によって起る場合があるこ とを明らかとしている。

ボルテラの数学モデルによると, 競合関係にある A B 2 種の生物群集の安定状態は, 2 つの基本的パラ メーターの值によって 4 つの可能な場合に分類される。すなわちAの及生存可能, B の及生存可能, A B 2 種共存, 条件に応じて $\mathrm{A}$ か $\mathrm{B}$ どちらか 1 種のみ生存可能, という 4 つの場合に分かれる。申請者は, 環 境条件を反映する 2 つパラメーターと，個体数密度の張る直積空問の中で，この定常值によって作られ る多様体を考光, その幾何学的不連続性に着目した。まず, 環境条件が連続的変化を示す 1 次元領域を, パラメーター空間の中の直線領域に対応させ, 遷移の過程で起る環境因子の変化に応じて起るパラメータ 一空間の直線領域の移動を調べ，上記多様体の幾何学的特異点を横切る時点で， 2 種の空間分布に不連続 的な境界が出現することを証明した。

さらに，植物生態系の遷移でみられる優先種の移り変りの過程を，環境因子の変化にともなら多様体上 の代表点の動きによって考察できることに着目し, 中間状態を経過せずに急澈な種の交代が起る場合があ 
ることを明らかにした。すなわら，徐々に優先種が交代していく場合と，ある時点で急激に種の交代が起 る場合が，環境因子の変化の道筋の微妙な違いによって出現することを証明している。

参考論文 1 では，たがいに慨と捕食者の関係にある 3 種の生物群集の共存条件とその安定性について, コルモゴロフ形の方程式を 3 種系に拡張することによって解析し, 安定性の条件を詳しく調べている。参 考論文 2 は, 生態系の数学モデルにあらわれるカタストローフを論じたもので, 主論文と密接に関係した 研究を報告したものである。

参考論文 3 は, 生態系の構造と安定性, さらに効唁といら問題を綜合的に解析することを目的とした組 織的研究をまとめたものであり，さらに参考論文 4 では，生物群集に捛ける種間特よび種内のいろいるな 相互作用が系の安定性にいかに関係しているかを解析している。

\section{論文審查の結果の要旨}

時間的めるいは空間的に連続的な变化をする環境条件下に括いて，植物群集の空間的分布や時間的逗移 の過程でしばしば不連続的な变化が出現することはよく知られた事実である。この不連続性の出現の機構 を明らかにすることは生態学的にも興味ある重要な問題である。

申請者は，たがいに競合関係にある 2 種の植物の個体数密度の变化を記述するボルテラ形方程式を基礎 にして，個体数密度の張る現象空間と，2 個の基本的パラメーターで張られるパラメーター空間の直積空 間内で, 力学的安定点によって作られる多様体の幾何学的構造の不連続性に着目した。連続的に環境条件 が変化しているじっさいの植物群落の領域は，このパラメーター空間のある領域に対応つけることができ る。申請者は，遷移の過程での環境因子の変化にともならこのパラメーター空間の領域の移動が，上記多 㥞体の幾何学的特異点を横切る時点で，2 種の植物分布相に不連続的境界が形成されることを証明してい る。

さらに申請者は，遷移における優先種の交代の過程をこのパラメーター空間の代表点の移動によって 考察し，徐々に優先種が入れかわる場合と，ある時点で急激な交代が実現する場合とが，環境因子の変化 の仕方の 微妙な違いによって区別されることを，同じ多様体のトポロジカルな性質を用いて証明してい る。

植物生態系に和けるこれらの不連続的な現象の発現機構を, 比較的簡単な数学的モデルを基礎にして巧 妙な手法を用いて解析したもので，植物生態系の遷移に関するまったく新しい知見を提示したものとし て，関連分野に重要な寄与をしたものとい方る。また，カタストロフ理論の具体的な興味ある例を提示し たものとしての意義も大である。

また，参考論文 4 編は，生物集団の変動と安定性さらにその構造と機能に関する数学的解析を行ったも ので，いずれも数理生態学の分野に寄与するところが少なくない。主論文，参考論文を通じて，申請者が この分野で豊富な学識と，きわめて秀れた研究能力をもっていることを認めることができる。

よって, 本諭文は理学博士の学位論文として洒值あるものと認める。 